\title{
Effect of peripartum nutritional management on plasma profile of steroid hormones, metabolites, and postpartum fertility in buffaloes
}

\author{
R. M. Kalasariya, A. J. Dhami, K. K. Hadiya, D. N. Borkhatariya and J. A. Patel \\ Department of Animal Reproduction Gynaecology \& Obstetrics, College of Veterinary Science \& Animal Husbandry, AAU, \\ Anand, Gujarat, India. \\ Corresponding author: A. J. Dhami, e-mail: ajdhami@aau.in, \\ Co-authors: RMK: kalasariya.rajesh@gmail.com, KKH: kamleshhadiya@yahoo.co.in, \\ DNB: devasee94@gmail.com, JAP: japatel@aau.in \\ Received: 24-09-2016, Accepted: 25-01-2017, Published online: 12-03-2017
}

doi: 10.14202/vetworld.2017.302-310 How to cite this article: Kalasariya RM, Dhami AJ, Hadiya KK, Borkhatariya DN, Patel JA (2017) Effect of peripartum nutritional management on plasma profile of steroid hormones, metabolites, and postpartum fertility in buffaloes, Veterinary World, 10(3): 302-310.

\begin{abstract}
Aim: The aim of this study was to evaluate the influence of peripartum protein and minerals supplementation on plasma profile of steroid hormones, metabolites, and fertility in rural buffaloes.

Material and Methods: A total of 85 advanced pregnant ( $\sim 8$ months) pluriparous buffaloes selected at farmers' doorstep in three tribal villages of Middle Gujarat were randomly divided into two groups, viz., control $(\mathrm{n}=45)$ and nutrients treatment $(40)$. The buffaloes of treatment group $(\mathrm{n}=40)$, in addition to farmers feeding schedule/control, received daily $1.5 \mathrm{~kg}$ compound concentrate mixture (22\% CP) and $50 \mathrm{~g}$ of chelated ASMM for 2 months each pre- and post-partum. Further, 15 buffaloes, each of control and treatment group, were injected parentrally (deep i/m) with $5 \mathrm{ml}$ of micro-minerals (each ml containing $\mathrm{Se}, \mathrm{Zn}, \mathrm{Cu}$ and $\mathrm{Mn}$ at 5, 40, 15 and $10 \mathrm{mg}$, respectively), twice 2 months before and on the day of calving, keeping rest of the animals (control, $\mathrm{n}=30$ and treatment, $\mathrm{n}=25$ ) as controls. Blood sampling was done on days $-60,-30,-15,0,15,30,45$, and 60 peripartum for estimation of plasma progesterone and estradiol by standard RIA techniques and other metabolites using assay kits on biochemistry analyzer. The puerperal events and postpartum fertility were monitored through history and by fortnightly palpation per rectum till day 45 and then again at 120 days postpartum for both the groups and subgroups.
\end{abstract}

Results: The mean plasma progesterone concentrations in all groups declined significantly $(\mathrm{p}<0.05)$ from day 60 to day 15 prepartum, reached to the basal levels $(<0.5 \mathrm{ng} / \mathrm{ml})$ on the day of parturition, and subsequently, reduced nonsignificantly till day 15 postpartum and then showed a rising trend from day 30 to 60 postpartum with significantly higher values at day 45 and/or 60. The mean plasma estradiol values increased with approaching parturition and were at its peak on the day of calving $(\mathrm{p}<0.01)$. Thereafter, there was a rapid fall in the levels by day 15 and it remained low till day $45-60$ postpartum. The blood glucose values showed an increasing trend with advancing gestation, reaching the highest on the day of calving, dropped significantly $(\mathrm{p}<0.01)$ within 15 days postpartum, and thereafter showed consistent values. The buffaloes supplemented with peripartum nutrients maintained significantly $(\mathrm{p}<0.05)$ higher blood glucose concentrations than the control during the peak lactation. The plasma protein levels varied significantly $(p<0.05)$ between days within the group with the lowest values on the day of calving, as well as between groups with higher $(\mathrm{p}<0.05)$ values on day 30 and 60 postpartum in treated group. Micro-minerals injected did not reveal significant influence on steroid hormones, blood glucose, or plasma protein. The mean plasma total cholesterol was significantly lower $(\mathrm{p}<0.05)$ in treatment than the control group. The mean values in micro-minerals injected subgroup were higher than the non-injected control subgroup during postpartum phase. The mean plasma triglyceride values in the pregnant buffaloes under both the groups and subgroups gradually decreased as parturition approached with significantly lowest values on the day of calving. The values increased nonsignificantly by day 15 and then remained steady throughout postpartum period without influence of nutrient supplementation or micro-minerals injection. The incidence of retained fetal membranes (RFMs) was 5.00 and $13.33 \%$ in treatment and control groups, respectively, with placental expulsion time of $3.27 \pm 0.37$ and $4.44 \pm 0.53 \mathrm{~h}(\mathrm{p}>0.05)$. The micro-minerals injection appreciably reduced the incidence of RFMs and significantly $(\mathrm{p}<0.05)$ reduced the placental expulsion time over non-injected controls. In treatment group, the period for involution of uterus was significantly shorter ( $29.39 \pm 0.50 \mathrm{vs.} 32.12 \pm 0.82$ days, $p<0.05)$, with early onset of first postpartum estrus ( $67.65 \pm 1.67$ vs. $79.43 \pm 3.06$ days, $p<0.01$ ), shorter service period ( $90.89 \pm 4.41$ vs. $105.09 \pm 4.76$ days, $\mathrm{p}<0.05)$ and higher conception rate $(55.00$ vs. $40.00 \%)$ than in control group. The micro-minerals injection apparently and/ or significantly improved all these traits in both the groups. Thus, the postpartum reproductive performance was significantly improved in treated than control groups and subgroups.

Conclusion: The results showed that nutrient supplementation in terms of high protein concentrate, ASMM and injection of sustained release micro-minerals ( $\mathrm{Se}, \mathrm{Zn}, \mathrm{Cu}$, and $\mathrm{Mn}$ ) during transition period minutely altered the plasma steroid hormones and blood metabolites though it significantly improved the postpartum reproductive performance in buffaloes under field conditions.

Keywords: buffalo, hormone and metabolic profile, postpartum fertility, protein and mineral supplementation, transition period.

Copyright: Kalasariya, et al. Open Access. This article is distributed under the terms of the Creative Commons Attribution 4.0 International License (http://creativecommons.org/licenses/by/4.0/), which permits unrestricted use, distribution, and reproduction in any medium, provided you give appropriate credit to the original author(s) and the source, provide a link to the Creative Commons license, and indicate if changes were made. The Creative Commons Public Domain Dedication waiver (http://creativecommons.org/publicdomain/zero/1.0/) applies to the data made available in this article, unless otherwise stated. 


\section{Introduction}

Buffalo is the premier dairy animal in the developing countries of Asia and it is the mainstay of the Indian dairy industry. The peripartum period plays a pivotal role in buffalo reproduction. The poor nutrition is one of the main factors for periparturient complications, metabolic disorders, low milk production and long calving intervals in dairy cattle and buffaloes, all of which contribute to low reproductive performance and productive losses leading to reduced income. A major factor of economic importance in buffalo reproduction is the postpartum fertility.

In dairy bovines, a low energy level during early puerperium delayed uterine involution and onset of ovarian activity and prolonged the postpartum estrus interval and service period [1-3]. The optimum nutritional management in terms of energy, protein, minerals, enzymes and use of oral/parentral antioxidants such as vitamin E, selenium, iodine, and essential micro-nutrients such as zinc, copper, and manganese during transition period has been reported to be highly beneficial in reducing periparturient disorders and enhancing uterine involution with improved postpartum fertility and productivity in dairy cows and buffaloes by many researchers [1-4], but very few have studied its effect on steroid hormone and metabolic profile in buffaloes under field conditions.

Therefore, this study was planned to evaluate whether the nutrient management of transition period influence the peripartum plasma profile of steroid hormones, metabolites, and postpartum fertility in buffaloes under field conditions.

\section{Materials and Methods}

\section{Ethical approval}

The prior approval from the Institutional Animal Ethics Committee was obtained for the use of farmers animals in this study.

\section{Selection and treatment of animals}

For this study, 85 advanced pregnant ( $\sim 8$ months) pluriparous buffaloes of $2^{\text {nd }}$ to $4^{\text {th }}$ parity (400-425 kg b.wt.) were selected in 3 tribal villages of Mahisagar District in Gujarat. The experiment was initiated at about 2 months prepartum by dividing the selected animals randomly into control and treatment groups in each village. All the registered animals were maintained hygienically at farmers' doorstep and fed green fodder $(8-10 \mathrm{~kg})$, dry paddy/maize straw (5-7 kg), home-made cattle feed or compound concentrate - Panchamrut dan (1.5-2.0 kg $+2 \mathrm{~kg}$ during early lactation) and mineral mixture (30-35 g), as per farmers feeding practices in the region. The buffaloes of treatment group, in addition to farmers feeding schedule/control, received daily extra $1.5 \mathrm{~kg}$ compound concentrate mixture $(22 \% \mathrm{CP})$ and $50 \mathrm{~g}$ of area specific chelated mineral mixture (developed by AAU, Anand) for 4 months ( 2 months prepartum and 2 months postpartum). Further, the animals of both control and treatment groups were randomly subgrouped for parentral injection of sustained release micro-minerals. The buffaloes of subgroup-I ( $\mathrm{n}=15$ each) were additionally injected with $5 \mathrm{ml}$ of micro-minerals (each $\mathrm{ml}$ containing $\mathrm{Se}, \mathrm{Zn}, \mathrm{Cu}$, and $\mathrm{Mn}$ at 5, 40, 15, and $10 \mathrm{mg}$, respectively), twice 2 months before and on the day of calving, while those of subgroup-II (control, $n=30$; treatment, $n=25$ ) served as micro-minerals controls.

The composition (on DM basis) of the chelated mineral mixture and concentrate used in the study was as under.

\begin{tabular}{|c|c|c|c|}
\hline \multicolumn{2}{|c|}{$\begin{array}{l}\text { Chelated mineral } \\
\text { mixture }(\%)\end{array}$} & \multicolumn{2}{|l|}{$\begin{array}{l}\text { Compounded } \\
\text { concentrate }(\%)\end{array}$} \\
\hline Calcium & 20.00 & Maize & 11.00 \\
\hline Phosphorus & 12.00 & Molasses & 10.00 \\
\hline Sulphur & 2.00 & Soya bean & 17.50 \\
\hline Zinc & 2.25 & De-oiled rice bran & 56.50 \\
\hline Manganese & 0.12 & Mineral mixture & 2.00 \\
\hline Cobalt & 0.014 & Salt & 1.00 \\
\hline Copper & 0.20 & Urea & 1.00 \\
\hline Iodine & 0.030 & Bypass fat & 1.00 \\
\hline
\end{tabular}

\section{General and reproductive health}

All the animals were appropriately vaccinated against foot and mouth disease and hemorrhagic septicemia and were dewormed using fenbendazole plus ivermectin bolus $3.0 \mathrm{~g}$ orally twice 2 months before and again on the day of calving. The animals were regularly monitored for periparturient events including calving, expulsion of the placenta, postpartum genital/general health, and the occurrence of first estrus postpartum. The uterine involution was assessed by per-rectal palpation at day 15, 30-35 and 45 postpartum. The buffaloes exhibiting estrus beyond 55-60 days postpartum were only inseminated. Pregnancy was confirmed per rectum 45 days after last AI. The reproductive status of each animal as to pregnant, cyclic, anestrus (ovaries without any functional structure, $\mathrm{CL}$ or follicle) or repeat breeder ( $>3$ repeat cycles) was ascertained by day 120 postpartum, to know the incidence of postpartum infertility.

\section{Blood sampling and assay technique}

Blood samples were collected from the representative animals of both the groups on the days -60 , $-30,-15,0,15,30,45$, and 60 peripartum by jugular vein puncture in heparinized vacutainers. Blood glucose was estimated soon using Accu-Chek Integra machine. The blood samples were immediately centrifuged, and plasma samples were stored deep frozen at $-20^{\circ} \mathrm{C}$ with a drop of Merthiolate $(0.1 \%)$ until analyzed. The levels of total protein, total cholesterol, and triglycerides were estimated using standard procedures and assay kits of Coral Clinical System, Goa on biochemistry analyzer. The plasma progesterone and estradiol concentrations were estimated by employing standard RIA techniques $[5,6]$. The sensitivity of progesterone assay was $0.1 \mathrm{ng} / \mathrm{ml}$. The intra- and inter-assay coefficients of variation were $5.4 \%$ and $9.1 \%$, respectively. The corresponding values for 
estradiol assay were $9.58 \mathrm{pg} / \mathrm{ml}, 14.4 \%$ and $14.5 \%$, respectively.

\section{Statistical analysis}

The data on puerperal events and reproductive performance were analyzed statistically using Chisquare test and t-test, and those on different blood profiles were analyzed statistically using ANOVA, DNMRT and t-test employing SPSS software version 20.00 [7] to compare differences between periods within the group and between treated and control groups as well as micro-minerals injected and non-injected subgroups on different days peripartum.

\section{Results and Discussion}

The results on puerperal events, reproductive performance, and fortnightly mean plasma profile of progesterone, estradiol-17 $\beta$, and metabolites recorded during 120 days peripartum period in buffaloes under nutrients treated and control groups and subgroups are presented in Figures-1 and 2 and Tables-1-7.

\section{Plasma progesterone profile}

The mean plasma progesterone $\left(\mathrm{P}_{4}\right)$ concentrations were maximum $(>4.5 \mathrm{ng} / \mathrm{ml})$ on day 60 prepartum in treatment and control groups, which declined significantly $(\mathrm{p}<0.05)$ on day 15 prepartum reaching to

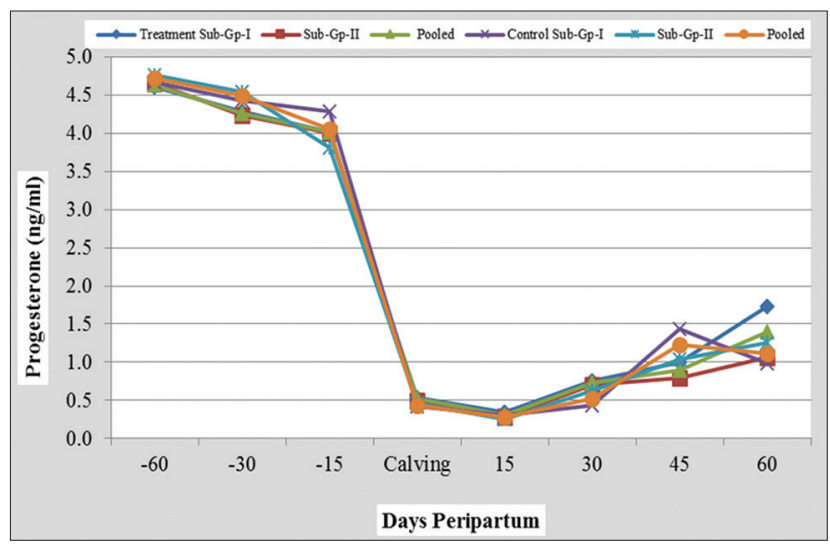

Figure-1: Peripartum plasma progesterone profile in nutrient supplemented and control groups of buffaloes (with their micro-minerals injected and non-injected subgroups).

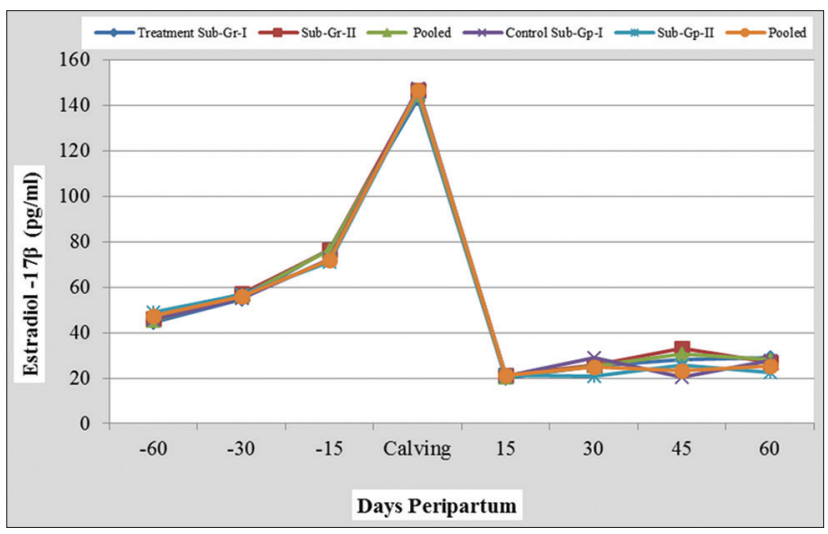

Figure-2: Peripartum plasma estradiol $17 \beta$ profile in nutrient supplemented and control groups of buffaloes (with their micro-minerals injected and non-injected subgroups). the basal levels $(<0.5 \mathrm{ng} / \mathrm{ml})$ on the day of parturition. Subsequently, these values reduced nonsignificantly till day 15 postpartum and then showed a rising trend on days 30,45 and 60 postpartum with significantly higher values at day 45 and/or 60 in different groups, suggesting presence of luteinized follicles and/or corpora lutea preceded by silent ovulations from day 45 onward postpartum. With respect to the effect of parentral injection of micro-minerals, no significant difference was observed in the mean progesterone values between treatment and control subgroups on any of the days studied. Similarly, the differences were also nonsignificant between nutrients treated and control groups on all the days, except on day 45 postpartum, where $\mathrm{P}_{4}$ was significantly higher $(\mathrm{p}<0.05)$ in control group than treatment group $(1.23 \pm 0.30 \mathrm{vs}$. $0.90 \pm 0.18 \mathrm{ng} / \mathrm{ml}$; Table-1 and Figure-1).

This trend of peripartum plasma progesterone concentration corroborated well with the earlier reports in buffaloes [8-11] and cattle [3,12]. In this study, basal value of $0.2-0.8 \mathrm{ng} / \mathrm{ml}$ found on the day of calving was suggestive of complete luteolysis at parturition and corroborated with the findings of previous workers [13-16]. The findings on the effect of protein and micro-minerals supplementation on plasma $\mathrm{P}_{4}$ corroborated well with those of Dhami et al. [3]. Due to prolonged period of inhibition during pregnancy from continuous negative-feedback effect of progesterone secreted by the corpus luteum and placenta, the pituitary becomes refractory to GnRH postpartum. However, during this postpartum phase, the ovaries frequently contain numerous large anovulatory follicles which quickly undergo atretia.

\section{Plasma estradiol-17 $\beta$ profile}

The pooled mean plasma estradiol-17 $\beta\left(\mathrm{E}_{2}\right)$ concentration in buffaloes of the control group increased gradually and significantly $(\mathrm{p}<0.01)$ from day 60 prepartum $(47.29 \pm 2.03 \mathrm{pg} / \mathrm{ml})$ to the day of calving $(146.79 \pm 3.55 \mathrm{pg} / \mathrm{ml})$. Thereafter, there was a sudden and significant $(\mathrm{p}<0.01)$ drop in the mean plasma estradiol level on day 15 postpartum $(21.07 \pm 1.39 \mathrm{pg} / \mathrm{ml})$. The mean values of plasma estradiol on days 30,45 and 60 postpartum were statistically at par with the value of day 15 postpartum. The mean values in the buffaloes under treatment group followed a trend similar to control group. The value on day 15 did not differ statistically from day 30 but was significantly $(p<0.05)$ lower as compared to those on day 45 and 60 postpartum (Table-2 and Figure-2). No significant differences were observed between subgroups of treatment and control groups on any of the days, except on day 30 in control group, where $\mathrm{E}_{2}$ was significantly $(\mathrm{p}<0.05)$ higher in micro-mineral injected

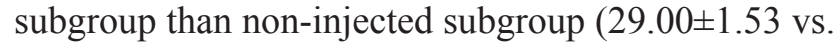
$21.00 \pm 2.02, \mathrm{pg} / \mathrm{ml}$ ), suggesting beneficial role of injectable micro-minerals used on days 60 prepartum and on the day of parturition in supporting early folliculogenesis. 
Table-1: Mean plasma progesterone concentrations during peripartum period in buffaloes under nutrients supplemented and control groups and subgroups.

\begin{tabular}{|c|c|c|c|c|c|c|}
\hline \multirow[t]{3}{*}{ Days peripartum } & \multicolumn{6}{|c|}{ Plasma progesterone concentration $(\mathrm{ng} / \mathrm{ml})$} \\
\hline & \multicolumn{3}{|c|}{ Treatment group } & \multicolumn{3}{|c|}{ Control group } \\
\hline & $\begin{array}{l}\text { Subgroup-I } \\
\qquad(n=9)\end{array}$ & $\begin{array}{c}\text { Subgroup-II } \\
(n=9)\end{array}$ & $\begin{array}{l}\text { Pooled } \\
(n=18)\end{array}$ & $\begin{array}{c}\text { Subgroup-I } \\
(\mathbf{n = 7 )}\end{array}$ & $\begin{array}{c}\text { Subgroup-II } \\
\qquad(n=7)\end{array}$ & $\begin{array}{l}\text { Pooled } \\
(n=14)\end{array}$ \\
\hline-60 & $4.60 \pm 0.16^{c}$ & $4.66 \pm 0.16^{c}$ & $4.63 \pm 0.11^{\mathrm{e}}$ & $4.67 \pm 0.19^{c}$ & $4.76 \pm 0.11^{d}$ & $4.72 \pm 0.11^{\mathrm{d}}$ \\
\hline-30 & $4.28 \pm 0.14^{c}$ & $4.24 \pm 0.18^{c}$ & $4.26 \pm 0.11^{\text {de }}$ & $4.43 \pm 0.19^{c}$ & $4.54 \pm 0.27^{c d}$ & $4.49 \pm 0.16^{\mathrm{cd}}$ \\
\hline-15 & $4.02 \pm 0.07^{c}$ & $4.00 \pm 0.14^{c}$ & $4.01 \pm 0.14^{\mathrm{d}}$ & $4.29 \pm 0.16^{c}$ & $3.81 \pm 0.24^{c}$ & $4.05 \pm 0.15^{c}$ \\
\hline 0 & $0.54 \pm 0.07^{a}$ & $0.50 \pm 0.06^{\mathrm{ab}}$ & $0.52 \pm 0.05^{\mathrm{ab}}$ & $0.42 \pm 0.10^{\mathrm{a}}$ & $0.46 \pm 0.06^{\mathrm{ab}}$ & $0.44 \pm 0.06^{a}$ \\
\hline 15 & $0.35 \pm 0.06^{a}$ & $0.28 \pm 0.05^{a}$ & $0.31 \pm 0.04^{a}$ & $0.31 \pm 0.07^{a}$ & $0.25 \pm 0.03^{a}$ & $0.28 \pm 0.04^{a}$ \\
\hline 30 & $0.76 \pm 0.31^{a}$ & $0.70 \pm 0.27^{\mathrm{ab}}$ & $0.73 \pm 0.20^{\mathrm{ab}}$ & $0.43 \pm 0.14^{a}$ & $0.63 \pm 0.17^{\mathrm{ab}}$ & $0.53 \pm 0.11^{\mathrm{a}}$ \\
\hline 45 & $1.00 \pm 0.22^{\mathrm{a}}$ & $0.79 \pm 0.29 \mathrm{ab}$ & $0.90^{p} \pm 0.18^{b}$ & $1.43 \pm 0.51^{b}$ & $1.04 \pm 0.34^{\mathrm{ab}}$ & $1.23^{\mathrm{a}} \pm 0.30^{\mathrm{b}}$ \\
\hline 60 & $1.73 \pm 0.48^{b}$ & $1.06 \pm 0.45^{b}$ & $1.40 \pm 0.33^{c}$ & $0.98 \pm 0.39^{\mathrm{ab}}$ & $1.26 \pm 0.68^{\mathrm{b}}$ & $1.12 \pm 0.38^{\mathrm{b}}$ \\
\hline
\end{tabular}

Subgroup-I=Micro-minerals $5 \mathrm{ml}$ i/m, Subgroup-II=Micro-minerals control, Day $0=$ Day of calving. Means bearing uncommon superscripts within the column (abcde) differ significantly between periods and those within the row (pq) differ significantly between pooled values $(p<0.05)$

Table-2: Mean plasma estradiol- $17 \beta$ concentrations during peripartum period in buffaloes under nutrients supplemented and control groups and subgroups.

\begin{tabular}{|c|c|c|c|c|c|c|}
\hline \multirow[t]{3}{*}{ Days perpartum } & \multicolumn{6}{|c|}{ Plasma estradiol-17 $\beta$ concentration $(\mathrm{pg} / \mathrm{ml})$} \\
\hline & \multicolumn{3}{|c|}{ Treatment group } & \multicolumn{3}{|c|}{ Control group } \\
\hline & $\begin{array}{l}\text { Subgroup-I } \\
\qquad(n=9)\end{array}$ & $\begin{array}{l}\text { Subgroup-II } \\
\qquad(n=9)\end{array}$ & $\begin{array}{l}\text { Pooled } \\
(n=18)\end{array}$ & $\begin{array}{l}\text { Subgroup-I } \\
\qquad(n=7)\end{array}$ & $\begin{array}{l}\text { Subgroup-II } \\
\qquad(n=7)\end{array}$ & $\begin{array}{l}\text { Pooled } \\
(n=14)\end{array}$ \\
\hline-60 & $44.33 \pm 4.23^{b}$ & $46.00 \pm 2.57 c$ & $45.17 \pm 2.41^{c}$ & $45.71 \pm 2.44^{c}$ & $48.86 \pm 3.34^{b}$ & $47.29 \pm 2.03^{b}$ \\
\hline-30 & $54.78 \pm 4.77^{c}$ & $57.02 \pm 3.51^{d}$ & $55.89 \pm 2.89^{d}$ & $55.14 \pm 2.31^{d}$ & $56.71 \pm 3.39^{b}$ & $55.93 \pm 1.98^{c}$ \\
\hline-15 & $76.67 \pm 4.04^{d}$ & $76.44 \pm 3.42^{\mathrm{e}}$ & $76.56 \pm 2.57^{e}$ & $72.43 \pm 1.53^{\mathrm{e}}$ & $71.00 \pm 3.56^{c}$ & $71.71 \pm 1.87^{d}$ \\
\hline 0 & $143.11 \pm 4.55^{\mathrm{e}}$ & $146.56 \pm 5.00^{f}$ & $144.83 \pm 3.31^{f}$ & $147.71 \pm 3.93^{f}$ & $145.56 \pm 6.24^{\mathrm{d}}$ & $146.79 \pm 3.55^{\mathrm{e}}$ \\
\hline 15 & $19.89 \pm 2.54^{a}$ & $21.33 \pm 2.89^{a}$ & $20.61 \pm 1.87^{a}$ & $20.86 \pm 1.65^{a}$ & $21.29 \pm 2.37^{a}$ & $21.07 \pm 1.39^{a}$ \\
\hline 30 & $25.33 \pm 1.94^{a}$ & $25.67 \pm 1.79 \mathrm{ab}$ & $25.50 \pm 1.28^{\mathrm{ab}}$ & $29.00^{x} \pm 1.53^{b}$ & $21.00^{y} \pm 2.02^{\mathrm{a}}$ & $25.00 \pm 1.65^{\mathrm{a}}$ \\
\hline 45 & $28.33 \pm 3.07^{a}$ & $32.89 \pm 2.97^{b}$ & $30.61 \pm 2.15^{b}$ & $25.86 \pm 2.55^{\mathrm{ab}}$ & $20.57 \pm 1.23^{a}$ & $23.21 \pm 1.54^{a}$ \\
\hline 60 & $29.00 \pm 3.22^{\mathrm{a}}$ & $27.11 \pm 3.49^{\mathrm{ab}}$ & $28.06 \pm 2.32^{b}$ & $27.71 \pm 3.95^{\mathrm{ab}}$ & $22.57 \pm 2.62^{\mathrm{a}}$ & $25.14 \pm 2.39^{a}$ \\
\hline
\end{tabular}

Subgroup-I=Micro-minerals $5 \mathrm{ml}$ i/m, Subgroup-II=Micro-minerals control, Day $0=$ Day of calving. Means bearing uncommon superscripts within the column (abcdef) differ significantly between periods and those within the row (xy) differ significantly between sub-groups $(p<0.05)$

The present overall trend of peripartum estradiol-17 $\beta$ profile coincided well with that reported by many earlier researchers in buffaloes $[8,9,11,14,17,18]$ and in cattle [3,12]. It is well-established fact that after parturition the levels of plasma progesterone and estradiol- $17 \beta$ markedly decrease and fluctuate at basal levels until the initiation of postpartum follicular activity, ovulation and CL formation. However, nutrients supplemented did not influence significantly the levels of these hormones during the entire transition period of 120-day studied in rural buffaloes.

\section{Blood glucose}

The mean blood glucose values showed an increasing trend $(p<0.05)$ from day 60 prepartum with advancing gestation, reaching the highest on the day of parturition, dropped significantly $(p<0.01)$ within 15 days postpartum, and thereafter showed consistent values during postpartum periods in both treatment and control groups. The buffaloes of treatment group maintained significantly $(p<0.05)$ higher mean blood glucose concentrations than the control buffaloes during the peak lactation around days $30-60$ postpartum and thereby the pooled values $(51.30 \pm 0.60 \mathrm{vs}$. $49.40 \pm 0.71 \mathrm{mg} / \mathrm{dl})$. The mean plasma glucose levels were significantly $(\mathrm{p}<0.05)$ lower for 2 weeks before and 2 weeks after parturition in micro-minerals injected nutrient supplemented subgroup as compared to non-injected subgroup, and thereby the overall pooled means ( $49.76 \pm 0.78$ vs. $52.83 \pm 0.88 \mathrm{mg} / \mathrm{dl})$, but no such effect was found in control group (Table-3). This change may be associated with certain trace minerals injected and its role in body metabolism through involvement as cofactors or catalysts in enzyme reactions. The hypoglycemia seen during early lactation following parturition may be attributed to heavy drain of glucose for lactose synthesis.

Like present observations, Singh et al. [11] also found higher glucose levels in nutrient supplemented than unsupplemented buffaloes $(68.97 \pm 2.75$ vs. $63.69 \pm 1.71 \mathrm{mg} / \mathrm{dl})$. However, Shelke et al. [19] did not observe such significant effect on plasma glucose among buffaloes fed rumen protected fat and protein for 60 days prepartum compared to control. Abdulkareem [20] also reported steady mean glucose values around calving and postpartum period. The highest mean blood glucose concentration observed on the day of parturition in both the control and treatment groups supported the earlier findings in 
buffaloes [21,22] and crossbred cows [3,23]. They attributed the rise in blood glucose level to increased stress hormone cortisol for gluconeogenesis to meet the sudden increased demand for rapid influx of energy for act of parturition and initiation of lactation. Setia et al. [24] recorded gradual and significant rise in blood glucose level from calving till $12^{\text {th }}$ week postpartum due to increased cortisol which leads to the production of glucose by gluconeogenesis in cows. The higher blood glucose concentration postpartum helps in maintaining positive energy balance and thereby initiating ovarian activity and early exhibition of postpartum estrus.

\section{Plasma total protein}

The observed mean levels of plasma total protein were found to be within the normal range and varied significantly $(p<0.05)$ between days within the group as well as between the groups with higher $(p<0.05)$ values on day 30 and 60 postpartum and in overall pooled mean $(7.84 \pm 0.05 \mathrm{vs} .7 .53 \pm 0.05 \mathrm{~g} / \mathrm{dl})$ in nutrient treatment than control group. The mean plasma total protein levels in both treatment and control groups of animals were significantly lower on the day of calving than other periods, particularly in the treatment group. Injection of micro-minerals did not reveal significant influence on plasma total protein (Table-4). It was seen that high protein concentrate supplementation had a beneficial effect on raising the plasma total protein values in the buffaloes under treatment group.

The lower mean plasma total protein values observed on the day of parturition in both the control and treatment groups of animals, however, did not corroborate with Ashmawy [21], who observed increased plasma total protein around parturition, while Abdulkareem [20] documented almost constant plasma total protein concentrations around parturition and postpartum periods. Consistently high level of total protein has been in the late trimester of pregnancy for the optimum secretion of gonadotropin releasing factors and number of other hormones needed in the culmination of the pregnancy. A significantly increased mean plasma total protein level in the treatment group as compared to control group on day 30 onward postpartum might be due to the effect of nutritional supplementation in the treatment group.

Table-3: Mean blood glucose levels during peripartum period in buffaloes under nutrients supplemented and control groups and subgroups.

\begin{tabular}{|c|c|c|c|c|c|c|}
\hline \multirow{3}{*}{$\begin{array}{l}\text { Days pre-and } \\
\text { postpartum }\end{array}$} & \multicolumn{6}{|c|}{ Blood glucose levels (mg/dl) } \\
\hline & \multicolumn{3}{|c|}{ Treatment group } & \multicolumn{3}{|c|}{ Control group } \\
\hline & $\begin{array}{l}\text { Subgroup-I } \\
\qquad(n=9)\end{array}$ & $\begin{array}{c}\text { Subgroup-II } \\
\qquad(n=9)\end{array}$ & $\begin{array}{l}\text { Pooled } \\
(n=18)\end{array}$ & $\begin{array}{c}\text { Subgroup-I } \\
(\mathbf{n = 7 )}\end{array}$ & $\begin{array}{l}\text { Subgroup-II } \\
\qquad(n=7)\end{array}$ & $\begin{array}{l}\text { Pooled } \\
(n=14)\end{array}$ \\
\hline-60 & $45.89 \pm 1.88^{\mathrm{a}}$ & $47.67 \pm 2.10^{a}$ & $46.28 \pm 1.41^{a}$ & $45.86 \pm 1.35^{a}$ & $45.29 \pm 1.13^{a}$ & $45.57 \pm 0.87^{a}$ \\
\hline-30 & $46.67 \pm 1.175^{\mathrm{ab}}$ & $49.11 \pm 2.12^{\mathrm{a}}$ & $47.89 \pm 1.36^{\mathrm{ab}}$ & $47.29 \pm 3.46^{a}$ & $46.86 \pm 2.15^{\mathrm{a}}$ & $47.07 \pm 1.96^{\mathrm{ab}}$ \\
\hline-15 & $44.78 \pm 1.84^{\mathrm{ax}}$ & $51.67 \pm 2.73^{\text {ay }}$ & $48.22 \pm 1.80^{\mathrm{abc}}$ & $47.57 \pm 3.19^{a}$ & $48.43 \pm 2.70^{\mathrm{a}}$ & $48.00 \pm 2.01^{\mathrm{ab}}$ \\
\hline 0 & $55.78 \pm 2.05^{d}$ & $61.67 \pm 2.65^{b}$ & $58.72 \pm 1.78^{e}$ & $60.29 \pm 3.97^{b}$ & $56.43 \pm 3.09^{b}$ & $58.36 \pm 2.48^{c}$ \\
\hline 15 & $49.00^{\times} \pm 1.39^{\mathrm{abc}}$ & $54.78^{y} \pm 1.86^{a}$ & $51.89 \pm 1.33^{\mathrm{bcd}}$ & $51.43 \pm 3.29^{a}$ & $50.14 \pm 2.56^{\mathrm{ab}}$ & $50.79 \pm 2.01^{b}$ \\
\hline 30 & $52.78 \pm 1.37^{c d}$ & $52.33 \pm 1.54^{\mathrm{a}}$ & $52.56^{p} \pm 1.00^{c d}$ & $50.14 \pm 2.58^{a}$ & $46.57 \pm 1.93^{a}$ & $48.36^{\mathrm{a}} \pm 1.62^{\mathrm{ab}}$ \\
\hline 45 & $52.56 \pm 1.67^{c d}$ & $53.22 \pm 1.81^{\mathrm{a}}$ & $52.89^{p} \pm 1.20^{d}$ & $47.00 \pm 1.75^{\mathrm{a}}$ & $48.00 \pm 1.89^{a}$ & $47.50^{\mathrm{a}} \pm 1.24^{\mathrm{ab}}$ \\
\hline 60 & $51.67 \pm 2.77^{\mathrm{bcd}}$ & $52.22 \pm 2.53^{a}$ & $51.94 \pm 1.82^{\mathrm{bcd}}$ & $51.00 \pm 2.05^{a}$ & $50.14 \pm 2.01^{\mathrm{ab}}$ & $50.57 \pm 1.38^{b}$ \\
\hline Overall & $49.76^{\times} \pm 0.78$ & $52.83^{y} \pm 0.88$ & $51.30^{p} \pm 0.60$ & $49.82 \pm 1.12$ & $48.98 \pm 0.86$ & $49.40^{a} \pm 0.71$ \\
\hline
\end{tabular}

Subgroup-I=Micro-minerals $5 \mathrm{ml}$ i/m, Subgroup-II=Micro-minerals control, Day $0=$ Day of calving. Means bearing uncommon superscripts within the column (abcd) differ significantly between periods and those within the row (xy) differ significantly between sub-groups and between groups $(p q)(p<0.05)$

Table-4: Mean plasma total protein levels during peripartum period in buffaloes under nutrients supplemented and control groups and subgroups.

\begin{tabular}{|c|c|c|c|c|c|c|}
\hline \multirow{3}{*}{$\begin{array}{l}\text { Days pre-and } \\
\text { postpartum }\end{array}$} & \multicolumn{6}{|c|}{ Plasma total protein levels (g/dl) } \\
\hline & \multicolumn{3}{|c|}{ Treatment group } & \multicolumn{3}{|c|}{ Control group } \\
\hline & $\begin{array}{l}\text { Subgroup-I } \\
\qquad(n=9)\end{array}$ & $\begin{array}{l}\text { Subgroup-II } \\
\qquad(n=9)\end{array}$ & $\begin{array}{l}\text { Pooled } \\
(n=18)\end{array}$ & $\begin{array}{l}\text { Subgroup-I } \\
\qquad(n=7)\end{array}$ & $\begin{array}{c}\text { Subgroup-II } \\
\qquad(n=7)\end{array}$ & $\begin{array}{l}\text { Pooled } \\
(n=14)\end{array}$ \\
\hline-60 & $7.77 \pm 0.18^{\mathrm{ab}}$ & $7.66 \pm 0.11^{\mathrm{b}}$ & $7.72 \pm 0.10^{\mathrm{bc}}$ & $7.81 \pm 0.24$ & $7.65 \pm 0.16^{\mathrm{ab}}$ & $7.73 \pm 0.14^{\mathrm{ab}}$ \\
\hline-30 & $8.16 \pm 0.16^{b}$ & $7.94 \pm 0.12^{\mathrm{b}}$ & $8.05 \pm 0.10^{c}$ & $7.74 \pm 0.25$ & $7.87 \pm 0.27^{b}$ & $7.81 \pm 0.18^{b}$ \\
\hline-15 & $8.00 \pm 0.20^{\mathrm{ab}}$ & $7.76 \pm 0.22^{\mathrm{b}}$ & $7.88 \pm 0.15^{b}$ & $7.75 \pm 0.21$ & $7.51 \pm 0.12^{\mathrm{ab}}$ & $7.63 \pm 0.12^{\mathrm{ab}}$ \\
\hline 0 & $7.26 \pm 0.32^{\mathrm{a}}$ & $7.35 \pm 0.13^{a}$ & $7.31 \pm 0.17^{a}$ & $7.53 \pm 0.16$ & $7.04 \pm 0.20^{\mathrm{a}}$ & $7.29 \pm 0.14^{a}$ \\
\hline 15 & $7.63 \pm 0.21^{\mathrm{ab}}$ & $7.80 \pm 0.04^{b}$ & $7.72 \pm 0.11^{\mathrm{b}}$ & $7.72^{x} \pm 0.12$ & $7.07^{y} \pm 0.09^{a}$ & $7.41 \pm 0.12^{\mathrm{ab}}$ \\
\hline 30 & $7.58^{x} \pm 0.17^{\mathrm{ab}}$ & $8.08^{y} \pm 0.10^{b}$ & $7.83^{\mathrm{p}} \pm 0.12^{\mathrm{bc}}$ & $7.63 \pm 0.12$ & $7.14 \pm 0.24^{\mathrm{a}}$ & $7.38^{\mathrm{a}} \pm 0.15^{\mathrm{ab}}$ \\
\hline 45 & $7.90 \pm 0.33^{\mathrm{ab}}$ & $7.81 \pm 0.19^{b}$ & $7.86 \pm 0.19^{\mathrm{bc}}$ & $7.76 \pm 0.07$ & $7.32 \pm 0.20^{\mathrm{ab}}$ & $7.54 \pm 0.12^{\mathrm{ab}}$ \\
\hline 60 & $7.82 \pm 0.21^{\mathrm{ab}}$ & $7.93 \pm 0.09^{b}$ & $7.87^{p} \pm 0.11^{b c}$ & $7.74 \pm 0.16$ & $7.19 \pm 0.23^{a}$ & $7.47^{a} \pm 0.16^{a b}$ \\
\hline Overall & $7.83 \pm 0.09$ & $7.85 \pm 0.05$ & $7.84^{p} \pm 0.05$ & $7.71^{x} \pm 0.06$ & $7.35^{y} \pm 0.08$ & $7.53^{a} \pm 0.05$ \\
\hline
\end{tabular}

Subgroup-I=Micro-minerals $5 \mathrm{ml} \mathrm{i/m}$, Subgroup-II=Micro-minerals control, Day $0=$ Day of calving. Means bearing uncommon superscripts within the column differ significantly between periods $(a b c)$ and those within the row differ between sub-groups $(x y)$ or groups $(p q)(p<0.05)$ 


\section{Plasma total cholesterol profile}

The mean plasma total cholesterol values in buffaloes under both treatment and control groups gradually and significantly $(\mathrm{p}<0.05)$ decreased during 60 days prepartum period with the lowest values on the day of calving. Thereafter, the values again gradually and significantly $(\mathrm{p}<0.05)$ increased in the subsequent days postpartum to reach the highest at days 30-60 postpartum. The overall mean plasma total cholesterol value of treatment group was significantly lower $(\mathrm{p}<0.05)$ than in control group $(55.30 \pm 1.29$ vs. $58.84 \pm 1.32 \mathrm{mg} / \mathrm{dl})$, and so also was the status at $30^{\text {th }}$ day prepartum $(55.73 \pm 3.15$ vs. $65.32 \pm 3.24 \mathrm{mg} / \mathrm{dl})$. The mean plasma total cholesterol values in micro-minerals injected control subgroup were found to be higher than the non-injected subgroup during the postpartum phase, thereby giving significantly $(\mathrm{p}<0.05)$ higher overall pooled mean (61.44 \pm 1.94 vs. $56.25 \pm 1.75 \mathrm{mg} / \mathrm{dl}$; Table-5).

A trend of significant decrease $(\mathrm{p}<0.05)$ observed in overall mean cholesterol value from 2 months prepartum till parturition and subsequent increase $(\mathrm{p}<0.05)$ till 2 months postpartum in this study corroborated well with the previous studies $[3,24,25]$. The observed trend of increasing plasma total cholesterol after calving might be associated with the initiation of ovarian activity and establishment of postpartum ovarian cyclicity. Cholesterol serves as a precursor for the synthesis of steroid hormones by ovarian thica and luteal cells. Progesterone not only prepares the uterus for implantation of the embryo but also helps to maintain pregnancy by providing nourishment to the conceptus. The fluctuated pattern of plasma cholesterol during the overall pregnancy periods was inversely associated with the patterns of plasma progesterone levels [26]. High levels of progesterone during pregnancy are always accompanied with decreasing cholesterol concentrations as a result of cholesterol catabolism to progesterone via cholesterol esterase. Lactation probably also affects the level of plasma total cholesterol, which acts as a fatty acid carrier in the form of cholesterol ester for milk synthesis. As a result, there is a gradual increase in plasma cholesterol level with advancing lactation. These reports and the present findings clearly proved that plasma total cholesterol, being precursor of steroid hormone, is closely associated with the physiological status of animal reproduction.

\section{Plasma triglyceride profile}

The mean plasma triglyceride values in buffaloes under both the groups and subgroups gradually decreased as parturition approached with significantly lowest values on the day of calving. The values increased nonsignificantly by day 15 and then remained steady throughout postpartum period. The triglyceride levels were neither influenced by nutrient supplementation nor with micro-minerals injection but were apparently/significantly higher during the prepartum than postpartum period. The mean plasma triglyceride levels between treatment and control groups did not reveal significant difference at any of the peripartum intervals, including overall pooled means (19.33 \pm 0.66 vs. $18.10 \pm 0.68 \mathrm{mg} / \mathrm{dl}$; Table-6).

The present observations of insignificant effect of nutrients and periods corroborated with the opinion of Guedon et al. [25] that triglyceride levels remained more or less constant without showing any relationship with the resumption of postpartum ovarian activity. The present findings also corroborated with the report of Shelke et al. [19] that no significant effect on plasma triglyceride $(24.09 \pm 1.47 \mathrm{vs} .21 .93 \pm 1.13 \mathrm{mg} / \mathrm{dl})$ occurred among buffaloes fed rumen protected fat and protein for 60 days prepartum compared to control. On the contrary, Singh et al. [11] reported significantly higher mean plasma triglyceride levels during prepartum, partum and postpartum periods in buffaloes supplemented with Asparagus racemosus than the control group.

\section{Puerperal events and postpartum fertility}

The buffaloes monitored for the occurrence of periparturient reproductive and metabolic disorders

Table-5: Mean plasma total cholesterol levels during peripartum period in buffaloes under nutrients supplemented and control groups and subgroups.

\begin{tabular}{|c|c|c|c|c|c|c|}
\hline \multirow{3}{*}{$\begin{array}{l}\text { Days pre-and } \\
\text { postpartum }\end{array}$} & \multicolumn{6}{|c|}{ Plasma total cholesterol concentration $(\mathrm{mg} / \mathrm{dl})$} \\
\hline & \multicolumn{3}{|c|}{ Treatment group } & \multicolumn{3}{|c|}{ Control group } \\
\hline & $\begin{array}{c}\text { Subgroup-I } \\
\qquad(\mathrm{n}=9)\end{array}$ & $\begin{array}{l}\text { Subgroup-II } \\
\qquad(n=9)\end{array}$ & $\begin{array}{l}\text { Pooled } \\
(n=18)\end{array}$ & $\begin{array}{c}\text { Subgroup-I } \\
\qquad(n=7)\end{array}$ & $\begin{array}{c}\text { Subgroup-II } \\
\qquad(n=7)\end{array}$ & $\begin{array}{l}\text { Pooled } \\
(n=14)\end{array}$ \\
\hline-60 & $62.14 \pm 5.45^{\mathrm{b}}$ & $63.18 \pm 5.72^{\mathrm{bc}}$ & $62.64 \pm 3.84^{\text {cd }}$ & $69.55 \pm 6.44^{b}$ & $67.12 \pm 6.52^{c}$ & $68.33 \pm 4.45^{\mathrm{d}}$ \\
\hline-30 & $54.89 \pm 4.20^{\mathrm{ab}}$ & $56.57 \pm 5.97 \mathrm{abc}$ & $55.73^{p} \pm 3.15^{b c}$ & $66.35 \pm 4.42^{b}$ & $64.29 \pm 4.98^{\mathrm{bc}}$ & $65.32^{q} \pm 3.24^{c c}$ \\
\hline-15 & $51.23 \pm 3.58^{\mathrm{ab}}$ & $52.66 \pm 7.12^{\mathrm{ab}}$ & $51.95 \pm 3.87^{\mathrm{ab}}$ & $57.86 \pm 5.34^{\mathrm{ab}}$ & $57.21 \pm 6.70^{\mathrm{abc}}$ & $57.53 \pm 4.12^{\mathrm{bc}}$ \\
\hline 0 & $43.24 \pm 3.29^{a}$ & $42.27 \pm 5.26^{a}$ & $42.76 \pm 3.01^{a}$ & $46.51 \pm 2.08^{a}$ & $45.82 \pm 4.64^{a}$ & $46.17 \pm 2.45^{a}$ \\
\hline 15 & $50.04 \pm 5.09^{a b}$ & $47.41 \pm 3.13^{\mathrm{ab}}$ & $48.73 \pm 3.02^{\mathrm{ab}}$ & $57.05 \pm 3.37^{\mathrm{ab}}$ & $50.15 \pm 3.05^{\mathrm{ab}}$ & $53.60 \pm 2.39^{a b}$ \\
\hline 30 & $55.24 \pm 6.26^{\mathrm{ab}}$ & $58.10 \pm 3.33^{\mathrm{bc}}$ & $56.67 \pm 3.46^{\mathrm{bcd}}$ & $61.18 \pm 3.41^{\mathrm{ab}}$ & $51.25 \pm 3.44^{\mathrm{ab}}$ & $56.21 \pm 2.70^{\mathrm{bc}}$ \\
\hline 45 & $58.70 \pm 4.04^{b}$ & $68.71 \pm 4.15^{c}$ & $63.71 \pm 3.06^{\mathrm{cd}}$ & $62.28 \pm 5.64^{\mathrm{ab}}$ & $56.40 \pm 2.79 a b c$ & $59.34 \pm 3.13^{\mathrm{bcc}}$ \\
\hline 60 & $63.69 \pm 2.47^{b}$ & $68.72 \pm 4.76^{c}$ & $66.27 \pm 2.27^{d}$ & $66.71 \pm 7.38^{b}$ & $57.72 \pm 1.69^{a b c}$ & $62.22 \pm 3.84^{\mathrm{bcc}}$ \\
\hline Overall & $54.15 \pm 1.65$ & $56.45 \pm 1.98$ & $55.30^{\mathrm{p}} \pm 1.29$ & $61.44^{x} \pm 1.94$ & $56.25^{\curlyvee} \pm 1.75$ & $58.84^{\mathrm{a}} \pm 1.32$ \\
\hline
\end{tabular}

Subgroup- $\mathrm{I}=$ Micro-minerals $5 \mathrm{ml} \mathrm{i} / \mathrm{m}$, Subgroup-II=Micro-minerals control, Day $0=$ Day of calving. Means bearing uncommon superscripts within the column differ significantly between periods (abcd) and those within the row differ between subgroups $(x y)$ or groups $(p q)(p<0.05)$ 
revealed only the incidence of retained fetal membranes (RMFs) as 5.00 and $13.33 \%$ in treatment and control groups, respectively. The time required for the expulsion of placenta was $3.27 \pm 0.37(1.15-12.00) \mathrm{h}$ in the treatment group and $4.44 \pm 0.53(2.15-14.00) \mathrm{h}$ in control group, which however did not differ significantly. Further, in both nutrient supplemented and control groups, the parentral injection of micro-minerals appreciably reduced the incidence of RMFs and significantly $(p<0.01)$ shortened the placental expulsion time over non-injected controls (Table-7). The period for uterine involution was significantly shorter in nutrients treated than control group $(29.39 \pm 0.50 \mathrm{vs}$. $32.12 \pm 0.82$ days, $\mathrm{p}<0.05)$. In treatment group, the mean intervals for first postpartum estrus $(67.65 \pm 1.67$ vs. $79.43 \pm 3.06$ days, $p<0.01)$ and service period $(90.89 \pm 4.41$ vs. $105.09 \pm 4.76$ days, $\mathrm{p}<0.05)$ were also significantly shorter with higher conception rates (55.00 vs. $40.00 \%)$ and lesser number of services per conception (1.58 vs. 2.28$)$ than in control group [27]. The micro-minerals injection apparently and/or significantly improved all these traits in both the groups. Further, the nutrient supplementation both oral and parentral reduced the incidence of postpartum anestrus and repeat breeding over controls by $8-12 \%$ at 120 days postpartum (Table-7).

The role of micronutrients, energy, and protein in animal reproduction is well established. Significant reduction in the expulsion time of fetal membranes with peripartum exogenous administration of vitamin $\mathrm{E}$ and $\mathrm{Se}$ [1] or iodine [2] has also been documented earlier in buffaloes. The earlier workers $[2,4,28-30]$ have also reported shorter periods for uterine involution in buffaloes fed prepartum ration supplemented with energy/bypass fat, protein, or iodine. The present findings on first postpartum estrus, service period and conception rates corroborated well with the previous reports $[1,31,32]$ for vitamin $\mathrm{E}$ and Se supplemented buffaloes. Similarly, many others $[2-4,26,29]$ found a beneficial effect of prepartum

Table-6: Mean plasma triglycerides levels during peripartum period in buffaloes under nutrients supplemented and control groups and subgroups.

\begin{tabular}{|c|c|c|c|c|c|c|}
\hline \multirow{3}{*}{$\begin{array}{l}\text { Days pre-and } \\
\text { postpartum }\end{array}$} & \multicolumn{6}{|c|}{ Plasma triglycerides levels $(\mathrm{mg} / \mathrm{dl})$} \\
\hline & \multicolumn{3}{|c|}{ Treatment group } & \multicolumn{3}{|c|}{ Control group } \\
\hline & $\begin{array}{c}\text { Subgroup-I } \\
(n=9)\end{array}$ & $\begin{array}{c}\text { Subgroup-II } \\
\qquad(n=9)\end{array}$ & $\begin{array}{l}\text { Pooled } \\
(n=18)\end{array}$ & $\begin{array}{l}\text { Subgroup-I } \\
\quad(n=7)\end{array}$ & $\begin{array}{l}\text { Subgroup-II } \\
\qquad(n=7)\end{array}$ & $\begin{array}{l}\text { Pooled } \\
(n=14)\end{array}$ \\
\hline-60 & $24.57 \pm 2.59^{b}$ & $23.69 \pm 2.96^{b}$ & $24.13 \pm 1.91^{c}$ & $23.20 \pm 3.14^{b}$ & $23.19 \pm 1.82^{c}$ & $23.20 \pm 1.74^{c}$ \\
\hline-30 & $25.47 \pm 3.19^{b}$ & $22.99 \pm 2.57^{b}$ & $24.23 \pm 2.01^{c}$ & $21.81 \pm 2.05^{\mathrm{ab}}$ & $21.14 \pm 1.59 \mathrm{bc}$ & $21.48 \pm 1.25^{b c}$ \\
\hline-15 & $24.84 \pm 2.58^{\mathrm{b}}$ & $20.50 \pm 1.93^{\mathrm{ab}}$ & $22.67 \pm 1.65^{b c}$ & $19.73 \pm 2.54^{\mathrm{ab}}$ & $20.67 \pm 2.43^{\mathrm{bc}}$ & $20.20 \pm 1.69^{b c}$ \\
\hline 0 & $14.46 \pm 1.97^{a}$ & $12.84 \pm 1.94^{\mathrm{a}}$ & $13.65 \pm 1.35^{\mathrm{a}}$ & $12.62 \pm 2.92^{\mathrm{a}}$ & $13.15 \pm 1.44^{\mathrm{a}}$ & $12.88 \pm 1.56^{a}$ \\
\hline 15 & $19.26 \pm 1.96^{\mathrm{ab}}$ & $14.59 \pm 2.41^{\mathrm{a}}$ & $16.93 \pm 1.61^{\mathrm{a}}$ & $15.70 \pm 2.47^{\mathrm{ab}}$ & $16.38 \pm 2.51^{\mathrm{ab}}$ & $16.04 \pm 1.69^{\mathrm{ab}}$ \\
\hline 30 & $18.55 \pm 2.60^{\mathrm{ab}}$ & $17.57 \pm 2.10^{\mathrm{ab}}$ & $18.06 \pm 1.62^{\mathrm{ab}}$ & $18.50 \pm 4.01^{\mathrm{ab}}$ & $15.99 \pm 1.95^{\mathrm{ab}}$ & $17.24 \pm 2.72^{\mathrm{ab}}$ \\
\hline 45 & $17.98 \pm 2.64^{\mathrm{ab}}$ & $16.05 \pm 2.64^{\mathrm{ab}}$ & $17.01 \pm 1.83^{\mathrm{a}}$ & $17.20 \pm 3.55^{\mathrm{ab}}$ & $16.56 \pm 2.62^{\mathrm{ab}}$ & $16.88 \pm 2.12^{\mathrm{ab}}$ \\
\hline 60 & $18.46 \pm 2.02^{\mathrm{ab}}$ & $17.48 \pm 2.50^{\mathrm{ab}}$ & $17.97 \pm 1.57^{\mathrm{ab}}$ & $18.61 \pm 3.60^{\mathrm{ab}}$ & $15.09 \pm 1.78^{\mathrm{ab}}$ & $16.85 \pm 1.99^{\mathrm{ab}}$ \\
\hline Overall & $20.45 \pm 0.94$ & $18.21 \pm 0.92$ & $19.33 \pm 0.66$ & $18.42 \pm 1.11$ & $17.77 \pm 0.81$ & $18.10 \pm 0.68$ \\
\hline
\end{tabular}

Subgroup-I=Micro-minerals $5 \mathrm{ml} \mathrm{i} / \mathrm{m}$, Subgroup-II=Micro-minerals control, Day $0=$ Day of calving. Means bearing uncommon superscripts within the column $(a b c)$ differ significantly between periods $(p<0.05)$

Table-7: Periparturient disorders, uterine involution, postpartum fertility and incidence of infertility in nutritionally supplemented and control groups of buffaloes.

\begin{tabular}{|c|c|c|c|c|c|c|}
\hline \multirow{2}{*}{$\begin{array}{l}\text { Puerperal events/postpartum } \\
\text { fertility }\end{array}$} & \multicolumn{3}{|c|}{ Treatment group } & \multicolumn{3}{|c|}{ Control group } \\
\hline & $\begin{array}{c}\text { Subgroup-I } \\
(n=15)\end{array}$ & $\begin{array}{c}\text { Subgroup-II } \\
(n=25)\end{array}$ & $\begin{array}{l}\text { Pooled } \\
(n=40)\end{array}$ & $\begin{array}{c}\text { Subgroup-I } \\
(n=15)\end{array}$ & $\begin{array}{l}\text { Subgroup-II } \\
(n=30)\end{array}$ & $\begin{array}{l}\text { Pooled } \\
(n=45)\end{array}$ \\
\hline Dystocia & $1(6.67)$ & $1(4.00)$ & $2(5.00)$ & $0(0.00)$ & $2(6.67)$ & $2(4.44)$ \\
\hline Retention of placenta & $0(0.00)$ & $2(8.00)$ & $2(5.00)$ & $1(6.80)$ & $5(16.70)$ & $6(13.33)$ \\
\hline Expulsion of placenta (h) & $2.05 \pm 0.16^{x}$ & $3.93 \pm 0.52^{y}$ & $3.27 \pm 0.37$ & $2.79 \pm 0.42^{x}$ & $5.76 \pm 0.78^{y}$ & $4.44 \pm 0.53$ \\
\hline Uterine involution (d) & $28.45 \pm 0.65$ & $29.90 \pm 0.67$ & $29.39 \pm 0.50^{a}$ & $31.54 \pm 1.28$ & $32.81 \pm 0.92$ & $32.12 \pm 0.82^{b}$ \\
\hline First PP estrus $(d)$ & $62.64 \pm 1.66^{x}$ & $70.40 \pm 2.22^{y}$ & $67.65 \pm 1.67^{a}$ & $74.69 \pm 4.36$ & $82.68 \pm 4.14$ & $79.43 \pm 3.06^{b}$ \\
\hline $\begin{array}{l}\text { Pregnancy rate within } 120 \text { days } \\
\text { postpartum }\end{array}$ & $10(66.67)$ & $12(48.00)$ & $22(55.00)$ & $8(53.33)$ & $10(33.33)$ & $18(40.00)$ \\
\hline Service period $(d)$ & $85.60 \pm 8.07$ & $96.18 \pm 5.90$ & $90.89 \pm 4.41^{\mathrm{a}}$ & $91.25 \pm 7.19^{x}$ & $116.43 \pm 4.08^{y}$ & $105.09 \pm 4.76^{b}$ \\
\hline $\begin{array}{l}\text { Number of services per } \\
\text { conception }\end{array}$ & 1.36 & 1.85 & 1.58 & 1.89 & 2.67 & 2.28 \\
\hline Overall infertility & $5(33.33)$ & $12(52.00)$ & $17(45.00)$ & $7(46.67)$ & $17(66.67)$ & $24(60.00)$ \\
\hline True anestrus & $1(6.67)$ & $3(12.00)$ & $4(10.00)$ & $2(13.33)$ & $6(20.00)$ & $8(17.78)$ \\
\hline Subestrus & $3(20.00)$ & $7(28.00)$ & $10(25.00)$ & $3(20.00)$ & $8(26.27)$ & $11(24.44)$ \\
\hline Repeat breeder & $1(6.67)$ & $2(8.00)$ & $3(7.50)$ & $2(13.33)$ & $3(10.00)$ & $5(11.11)$ \\
\hline
\end{tabular}

Subgroup-I=Stimvet $5 \mathrm{ml}$ i/m, Subgroup-II=Stimvet control. Figures in parentheses indicate percentage values. Means bearing different superscripts within the row differ significantly between groups $(a, b)$ or sub-groups $(x, y)$ within the group $(p<0.05)$ 
nutritional supplementation on early exhibition of first postpartum estrus in cattle and buffaloes as compared to control groups. The faster uterine involution with early onset of postpartum estrus and satisfactory conception rates have been attributed to combined effect of protein, minerals, and vitamins supplementation because of their positive effect on steroid synthesis and release, follicular growth and symptoms of ovulatory estrus [33]. Reproductive failure may be induced by malnutrition and deficiencies of single or combination of trace elements. An appreciable reduction in the incidence of postpartum anestrus and repeat breeding observed (8-12\%) over controls at 120 days postpartum in both oral and parentral nutrient supplemented groups substantiated the beneficial effect of oral as well as parentral supplementation of micro-minerals during transition period on puerperal events and postpartum fertility in buffaloes.

\section{Conclusion}

From the study, it was concluded that nutrients supplementation in terms of high protein concentrate, ASMM and injection of sustained release micro-minerals ( $\mathrm{Se}, \mathrm{Zn}, \mathrm{Cu}$, and $\mathrm{Mn}$ ) during transition period for 60-day pre- and post-partum minutely altered the plasma steroid hormones profile and blood metabolites, though it had significantly improved the postpartum reproductive performance in terms of the first estrus postpartum, service period and conception rates with lower incidence of infertility in buffaloes under field conditions, hence this practice may be advocated to the tribal farmers for better economic return from dairy animals.

\section{Authors' Contribution}

AJD and RMK planned and designed the study. The experiment was conducted and laboratory work was done by RMK, AJD, KKH, DNB and JAP. All authors participated in data analysis, preparation of draft of the manuscript, and read and approved the same.

\section{Acknowledgment}

We thank Dr. A.M. Thaker, Dean of the Veterinary Faculty as well as University authorities for the financial support, and tribal farmers and AI workers of concerned tribal villages for their kind cooperation in conduct of this valuable study.

\section{Competing Interests} interest.

The authors declare that they have no competing

\section{References}

1. Mavi, P.S., Pangaonkar, G.R. and Sharmn, R.K. (2006) Effect of vitamin $\mathrm{E}$ and selenium on postpartum reproductive performance of buffaloes. Indian J. Anim. Sci. 76: 308-310.

2. Zeedan, K.I.I., El-Malky, O.M.K., Mousa, M.M., El-Giziry, A.A. and Etman, K.E.I. (2010) Nutritional studies on different sources of iodine on productive performance, ruminal fermentation and blood constituents of buffalo. 1 - Effect of two different iodine levels on productive and reproductive performance of buffalo cows. J. Am. Sci., 6: 1090-1106.

3. Dhami, A.J., Theodore, V.K., Panchal, M.T., Hadiya, K.K., Lunagariya, P.M. and Sarvaiya, N.P. (2015) Effect of Peripartum Nutritional Supplementation on Postpartum Fertility and Blood Biochemical and Steroid Hormone Profile in Crossbred Cows. Proceedings XXXI Annual Convention of ISSAR and National Symposium, Hebbal, Bengaluru, December 3 to 5. p85.

4. Khan, H.M., Mohanty, T.K., Bhakat, M., Gupta, A.K., Tyagi, A.K. and Mondal, G. (2015) Effect of vitamin E and mineral supplementation on biochemical profile and reproductive performance of buffaloes. Buffalo Bull., 34(1): 63-72.

5. Kubasic, N.P., Hallauer, G.D. and Brodowns, R.G. (1984) Evaluation of direct solid phase RIA for progesterone, useful for monitoring luteal function. Clin. Chem., 30: 284-286.

6. Robertson, H.A. and King, G.J. (1979) Conjugated and unconjugated estrogens in fetal and meternal fluids of the cow throughout pregnancy. J. Reprod. Fertil., 55: 463-470.

7. Snedecor, G.W. and Cochran, W.G. (1994) Statistical Methods. $8^{\text {th }}$ ed. Iowa State University Press, Ames, Iowa, USA.

8. Prakash, B.S. and Madan, M.L. (1986) Peripheral plasma estradiol-17 $\beta$, progesterone and cortisol in buffaloes induced to calve with dexamethasone and vetoestrol. Anim. Reprod. Sci., 11: 111-122.

9. Savaiya, N.P., Mehta, V.M. and Patel, A.V. (1993) Blood serum estradiol-17 $\alpha$ and progesterone around parturition in Surti buffaloes. Indian J. Anim. Sci., 63: 294-295.

10. Shah, R.G., Dhami, A.J., Kharadi, V.B., Desai, P.M. and Kavani, F.S. (2004) Hormonal profile in fertile and infertile postpartum Surti buffaloes. Buffalo J., 20: 29-42.

11. Singh, S.P., Mehta, R.K. and Singh, M. (2012) Plasma hormones, metabolites, milk production, and cholesterol levels in Murrah buffaloes fed with Asparagus racemosus in transition and postpartum period. Trop. Anim. Health Prod., 44: $1827-1832$

12. Rawlings, N.C., Weit, L., Todd, B., Manns, J. and Hyland, J.H. (1980) Some endocrine changes associated with post-partum period of the suckling beef cows. J. Reprod. Fertil., 60: 301-308.

13. Kamonpatana, M. (1984) Application of Hormone Assay and Endocrine Pattern in Buffalo. In: Proceedings of the $10^{\text {th }}$ International Congress on Animal Reproduction and Artificial Insemination. Vol. IV. Urbana. p1-9.

14. El-Belely, M.S., Zaki, K. and Grunert, E. (1988) Plasma profiles of progesterone and total estrogens in buffaloes (Bubalus bubalis). J. Agric. Sci. Camb., 111: 519-524.

15. Momongan, V.G., Sarabia, A.S., Roxas, N.P., Palad, O.A., Obsioma, A.R., Nava, Z.M. and Del Barrio, A.N. (1990) Increasing the productive efficiency of Caraboas under small holder farming systems. In: Domestic Buffalo Production in Asia. IAEA, Vienna. p167-178.

16. Eissa, H.M. and El-Belely, M.S. (1995) Sequential changes in plasma progesterone, total estrogens, and corticosteroids in the cow throughout pregnancy and around parturition. Br. Vet. J., 146: 24-29.

17. Habeeb, A.A.M., Yousef, H.M., Zahed, S.M. and E-Ekhnawy, K.I. (1999) Female sex hormones and some blood components in relation to progress of pregnancy, fetal growth, parturition and stage of lactation in Friesian cows. Egypt. J. Appl. Sci., 14: 443-461.

18. Arya, J.S. and Madan, M.L. (2001) Postpartum reproductive cyclicity based on ovarian steroids in suckled and weaned buffaloes. Buffalo J., 17: 361-369.

19. Shelke, S.K., Thakur, S.S. and Amrutkar, S.A. (2011) Effect of postpartum supplementation of rumen protected fat and protein on the performance of Murrah buffaloes. Indian $J$. Anim. Sci., 81: 946-950. 
20. Abdulkareem, T.A. (2013) Some hematological and blood biochemical attributes of Iraqi riverine buffaloes (Bubalus bubalis) around calving and postpartum periods. Al-Anbar J. Vet. Sci., 6: 143-150.

21. Ashmawy, N.A. (2015) Changes in peripheral plasma hormone concentrations and metabolites during the last trimester of pregnancy and around parturition in the Egyptian buffalo and Baladi cows. Int. J. Adv. Res., 3(11): 1377-1390.

22. Abayawansa, W.D., Prabhakar, S., Singh, A.K. and Brar, P.S. (2013) Seasonal variations in blood metabolic profiles during peri and early postpartum period in winter and summer calved buffaloes. Indian J. Anim. Reprod., 34(1): 61-70.

23. Hadiya, K.K., Derashri, H.J. and Sarvaiya, N.P. (2010) Effect of minerals and enzymes supplementation on postpartum fertility and blood profile of progesterone and metabolites in crossbred cows. Indian J. Field Vet., 5(2): 33-36.

24. Setia, M.S., Duggal, R.S. and Singh, R. (1992) Biochemical constituents of blood in buffaloes and cows during late pregnancy and different stages of lactation - A longitudinal study. Buffalo J., 8(2): 123-129.

25. Guedon, L., Saumande, J., Dupron, F., Couquel, C. and Desbals, B. (1999) Serum cholesterol and triglycerides in postpartum beef cows and their relationship to the resumption of ovulation. Theriogenology, 51(7): 1405-1415.

26. Abdulkareem, T.A., Al-Sharifi, S.A., Eidan, S.M. and Sasser, R.G. (2012) Reproductive and productive performance of Iraqi buffaloes as influenced of pre-mating and pre-calving concentrate supplementation. Pak. Vet. J., 32(3): 345-348.

27. Kalasariya, R.M., Dhami, A.J., Hadiya, K.K. and Patel, J.A. (2017) Impact of protein and mineral supplementation during transition period on puerperal events and postpartum fertility in buffaloes. Indian J. Anim. Reprod., 38(1): 38-40.

28. Usmani, R.H., Dailey, R.A. and Inskeep, E.K. (1990) Effects of limited suckling and varying pre-partum nutrition on postpartum reproductive traits of milked buffaloes. J. Dairy Sci., 73: 1564-1570.

29. Ramteke, P.V., Patel, D.C., Parnerkar, S., Shankhpal, S.S., Patel, G.R. and Pandey, A. (2014) Effect of bypass fat supplementation during prepartum and postpartum on reproductive performance in buffaloes. Livest. Res. Int., 2(3): 54-58.

30. Hussein, H.A., Senosy, W. and Abdellah, M.R. (2013) Relationship among uterine involution, ovarian activity, blood metabolites and subsequent reproductive performance in Egyptian buffaloes. Anim. Sci., 3(1): 59-69.

31. Panda, N., Kaur, H. and Mohanty, T.K. (2006) Reproductive performance of dairy buffaloes supplemented with varying levels of vitamin E. Asian Australas. J. Anim. Sci., 19(1): 19-25.

32. Modi, L.C., Khasatiya, C.T., Patel, M.D. and Modi, F. (2016) Impact of vitamin E and Selenium administration during periparturient period on reproductive performance of Surti buffaloes. Indian. J. Anim. Reprod., 37(1): 30-31.

33. Srivastava, S.K. (2008) Effect of mineral supplement on oestrus induction and conception in anoestrus crossbred heifers. Indian J. Anim. Sci., 78(3): 275-276. 